\title{
Modeling of Financial Support for the Competitiveness of Employees in the Mining Industry
}

\author{
Iryna Perevozova ${ }^{[0000-0002-3878-802 X]}$, Nadiia Daliak ${ }^{[0000-0002-1599-842 X]}$ \\ Ivano-Frankovsk National Technical University of Oil and Gas, 1, Chopin Str., Ivano- \\ Frankivsk, 76000, Ukraine \\ perevozova@ukr.net, nadiya_d82@ukr.net \\ Vitalina Babenko ${ }^{[0000-0002-4816-4579]}$ \\ V. N. Karazin Kharkiv National University, 4, Freedom Sq., Kharkiv, 61022, Ukraine \\ vitalinababenko@karazin.ua
}

\begin{abstract}
The development of a socially oriented market economy in Ukraine, the effective implementation of reforms in this direction and the improvement of the well-being of the population is not possible without qualitative financial support for the competitiveness of workers, above all, in the mining industry. However, the absence of effective levers of influence on the organization of hightech production in this area, its considerable intensiveness of material and energy, and its complexity and harm have negatively affected the labor motivation of miners and the profitability of mining enterprises. Therefore, the urgent issues at the current stage of development of Ukraine's mining industry are determining the conditions and opportunities for increasing the competitiveness of employees in this industry. Scientific novelty of the results is to identify, substantiate and analyze the main stages of financial support for the competitiveness of workers in the mining industry under the conditions of a changing vector of the country's foreign economic policy and of market for products of this industry. The obtained results of the research are the basis to both the study and practical solution of the problem of how to increase the competitiveness of miners in enterprises under various forms of management. This approach involves not only a high level of material incentives for highly qualified specialists in mining, but also a comprehensive development of personnel potential in this industry as a whole.
\end{abstract}

Keywords: employee, mining industry, mining company, personnel management.

\section{$1 \quad$ Introduction}

The formation of high-tech production in Ukraine, effective implementation of reforms to this end, increase in gross domestic product and real incomes of citizens is only possible under the condition of high-quality financial support for the competitiveness of workers, above all, in the mining industry. However the lack of an effective program for the development of this industry and inhibition of its socio-economic reforms has 
negatively affected the attitude towards the work by miners and the quality of development of the mining industry as a whole. Thus, in 2014-2015, the number of registered unemployed in this industry exceeded other sectors in Ukraine by 4 times. At the same time, the profitability of operational activity of industrial companies in Ukraine for the above period decreased more than twice and amounted to less than $1 \%$ [1]. This situation destabilizes the industrial and economic security of the country, as well as the supply and demand of the labor market in this field.

Taking into account urgency and lack of solution for the aforementioned problem, the main goal of this study is to characterize financial support for the competitiveness of the mining industry workers and to develop measures for its improvement. To achieve this goal, we have identified the following main tasks:

- to form an apparatus of categories on the interpretation of the essence of the workers' competitiveness in the mining industry;

- to identify and characterize the main stages of financial support for the competitiveness of workers in this field;

- to propose measures for the effective implementation of the above-mentioned stages.

\section{Theory of the Matter}

The abovementioned matter has been researched by such scientists as: A. Cardoso [2], T. Chan, M. Egorova [3], P. Fedotov, E. Zelynskaya [4], G. Gayko, V. Beletsky [5], V. Ivanov, V. Komarov, P. Pavlov [6], S. Kozlov [7], S. Mahdevari, K. Shahriar, A. Esfahanipour [8], J. Maiti, S. Chatterjee, S. Bangdiwala [9], Y. Mossakovskyy [10], V. Nagornuy, V. Globa [11], L. Polishchuk [12], J. Prno [13], J. Ryfkyn [14] and so on. Thus, scientists have identified the basic principles for the development of mining and recreation of its labor resources. However, the problem of a complex appraisal of the competitiveness of miners under the conditions of a changing vector of foreign economic policy of the country and the market for products of this sector has not been researched sufficiently.

\section{Methodology of the Study}

The methodological basis of this study is a general scientific dialectical method of cognition, in which the object of the study is studied as a dynamic system in the process of development. Formation of an apparatus of categories of competitiveness of workers in the mining industry and the main stages of its financial support, carried out on the basis of dialectical, historical and systemic methods. In the process of studying and generalizing scientific and practical developments, methods of comparison, analysis and synthesis, induction and deduction have been applied. Additionally, the study is based on regulatory and economic documents, developments by research institutions and scientists.

Mining industry is one of the most traumatic, especially in underground work, where there is significant gas pollution and dust. Scientists at the University of Michigan [15] 
developed a model for assessing the individual cost of an employee, based on the notions of conditional and realized value.

The individual value of an employee depends on the expected probability that the employee will remain working and realizes his potential. That is, the realized cost of an employee:

$$
R V=U V * P(T),
$$

where $U V$ is the employee's standard cost, $P(T)$ - the probability that the employee works at the enterprise until the end of his working age $T$, taking into account the level of risks of the industry.

The conditional cost of a $U V$ employee characterizes all the potential profits an employee can bring to an organization if he has all the rest of his life working in it. Expected realized cost of an employee $R V$ characterizes the value of an employee, given the likelihood that he will remain in the organization for some time. The $R V$ poster is two-component: it consists of two elements: the expected conditional value of $U V$ and the probability of continuing membership in the organization $P(T)$. The last figure is the expectation of management about what part of the revenues will be realized in the organization to the expected time of dismissal of the employee. The mathematical model of these processes has the form:

$$
\begin{gathered}
P(Z)=1-P(T) ; \\
A V P=U V-R V=R V * P(Z),
\end{gathered}
$$

where $U V$ and $R V$ are expected conditional and realized costs;

$P(T)$ - the probability that the employee will remain in the organization after some time;

$P(Z)$ - the probability of dismissal of the employee from the organization or the rate of flow;

$A V P$ - alternative flow rates.

In this model, the cost of human resources is probabilistic. For organization, this may mean that not always the employee with the greatest potential will be the most useful company. And the HR manager, who seeks to optimize the cost of human resources, should prefer a candidate with the highest realized value, and not just the most capable.

For the measurement of the monetary form $U V$ and $R V$ developed stochastic positional model. It is implemented by such an algorithm:

1. the creation of a base of mutually exclusive positions or positions that can be occupied by an employee in the organization, that is, the formation of a career path of the employee - a sequential chain of positions or service statuses with the addition of such a state as the release from the enterprise;

2. determining the value of each position for the organization, that is, the profit that will be brought in the future by the employee while on this position. Moreover, the profit can be attributed to the person of the employee, and to the position that he occupies, as in the case of personal and positional restorative costs; 
3. determining the expectation of the term of human rights in the organization, that is, the assessment of the overall life of the person. It is influenced by many factors: individual expectations, the emotional and physical condition of the employee, the policy of the company in the area of staff recruitment and remuneration, mobility in the labor market, etc. All these factors are difficult to determine and measure, therefore, we can estimate the life of a person only from some probability. And, speaking of the expected life expectancy, we will have in mind the mathematical expectation of magnitude. There are two main ways of finding it: the method of expert evaluation and analytical;

4. the calculation of the probability that the employee will occupy each of the items specified in item 1 at a certain point in the future. To do this, on the basis of probabilistic assessments describe the expected career path of the employee up to release: with which probability each of the next year to the year of expected release from the organization employee will occupy each of the possible positions. In the last year of work the probability of dismissal should be equal to $100 \%$. This probability can be measured by two methods described in the third step. An analytical method involves three consecutive steps: collection of data on hiring, moving and dismissal; grouping data according to official status; compilation of matrices of probability of transitions;

5. discounting the expected future cash income to determine the present value.

The proposed model of employee valuation also describes the dependence of the cost of human resources on the degree of satisfaction. Therefore, satisfaction must be measured and communicated to the management of the organization.

In the absence of the necessary statistical information for the characterization and assessment of the competitiveness of the mining industry, in 2017 we have conducted a sociological survey in 1256 employees of mining industry Donetsk, Luhansk, Zaporizhia, Kharkiv, Dnipropetrovsk, Lviv, Volyn and Transcarpathia regions of Ukraine. Using a questionnaire developed by the author, their opinion on the level of competitiveness of workers in the mining industry has been studied.

Preliminarily, we had formed a set of basic features and characteristics that reflect various professional and socio-psychological features of miners and form their competitiveness in the labor market. The main ones are: gender, age, state of health, marital status and family composition, education, professional qualification level, work experience, conditions and work remuneration, computer skills, responsibility, and others. Respondents were asked to evaluate each of these criteria, based on their importance, and to express it in a ballistic assessment on a scale from 1 (minimum) to 50 (maximum) points. The survey was participated in by: heads of enterprises $(20 \%)$, heads of their structural divisions and leading specialists (30\%), and ordinary workers $(50 \%)$. Meaning, such groups of respondents, whose work is directly related to the definition and implementation of financial support for increasing the competitiveness in the mining industry, and those who are direct participants (performers) of individual production and technological processes. 


\section{Discussion of Results}

As a result of the analysis, we have established that there are different approaches to the interpretation of the essence of the competitiveness of workers in the mining industry. They are similar to each other and differ only in separate constituents. Thus, within this category most scholars understand the ability of a specialist to fully realize his right to work in the economic entity of the mining industry and receive appropriate remuneration for it $[2 ; 4-6 ; 8 ; 12-13]$.

Taking into account the interpretation of the socio-economic category described above, we have identified the main stages of financial support for the competitiveness of the mining industry (Fig. 1).

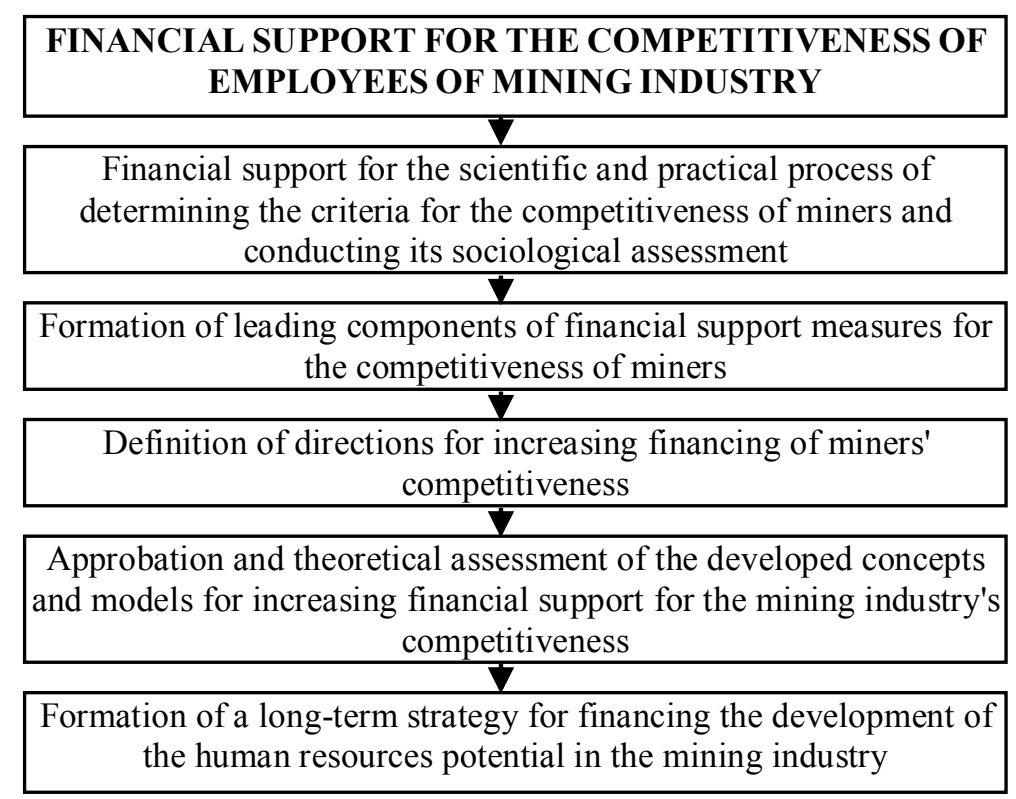

Fig. 1. Main stages of financial support for the competitiveness of mining workers

We believe that the proposed comprehensive methodological approach towards financial support for the competitiveness of mining workers will help identify its most important components and develop effective measures for their improvement.

In our opinion, the most significant of the above components is the financial support of the scientific and practical processes of determining the criteria for the competitiveness of miners and conducting its sociological assessment. Thus, appropriate funding allowed us to conduct monographic surveys to determine the main features and characteristics of the competitiveness of miners (Table 1).

Thus, the results of the above-mentioned sociological assessment of managers and employees of mining companies are different. Most managers and their deputies have set rather high requirements for the qualitative parameters of financial controllers and 
their work activities, namely: professional qualification level, work experience, gender, sense of responsibility, lack of bad habits, health status, family status and composition. This is evidenced by the high average mark -41.8 and the level of compliance with all the maximum possible parameters $-83.6 \%$.

Table 1. Assessment of the main features and characteristics of the competitiveness of the mining industry enterprises of Donetsk, Lugansk, Zaporizhzhya, Kharkiv, Dnipropetrovsk, Lviv, Volyn and Zakarpattia Regions, points.

\begin{tabular}{|l|c|c|c|}
\hline \multicolumn{1}{|c|}{ Feature, characteristic } & $\begin{array}{c}\text { Managers and their } \\
\text { deputies }\end{array}$ & $\begin{array}{c}\text { Hired } \\
\text { workers }\end{array}$ & Average \\
\hline $\begin{array}{l}\text { Requirements for conditions and } \\
\text { remuneration }\end{array}$ & 20 & 50 & 35.0 \\
\hline Education & 30 & 20 & 25.0 \\
\hline Professional qualification level & 50 & 30 & 40.0 \\
\hline Experience & 50 & 20 & 35.0 \\
\hline Gender & 50 & 10 & 30.0 \\
\hline Age & 30 & 20 & 25.0 \\
\hline Sense of responsibility & 50 & 30 & 40.0 \\
\hline Lack of bad habits & 50 & 35 & 42.5 \\
\hline Computer skills & 40 & 35 & 37.5 \\
\hline Health status & 50 & 50 & 50.0 \\
\hline Family status, composition & 40 & 30 & 35.0 \\
\hline Average points of feature, characteristic & 41.8 & 30.0 & 35.9 \\
\hline Compliance with all possible parameters, $\%$ & 83.6 & 60.0 & 71.8 \\
\hline
\end{tabular}

A more detailed analysis of the requirements of managers and their deputies contributed to identifying the priorities of this group of respondents regarding the requirements towards the applicant most appropriate for the position, whom they would prefer to employ in mining companies. In their opinion, this should be a male person, aged 18-40, with a professional qualification corresponding to the workplace, with or without work experience for this position for at least 5 years (for simple, unskilled and predominantly manual labor), who is responsible for fulfilling their duties and does not have bad habits (alcoholism, drug addiction, smoking). Thus, these qualities were evaluated by the respondents mentioned above with the maximum number of points. At the same time, heads of companies and structural units would like the applicant for the position have appropriate education and computer skills.

However, the requirements of hired workers of mining companies for competitiveness are much lower than those of managers and their deputies. For miners employed in non-executive positions, the following features are among the priorities for competitiveness: production conditions and value of labor are expressed by the level of remuneration, health status, age, marital status and family composition, etc. (average $30)$.

We believe that this situation reflects the relationship between the complexity of the work performed and the qualifications of its direct performers. As a result, differentiated requirements of employers and employees towards the characteristics of competitiveness of the latter are formed. So, if the work is predominantly typical, 
manual, or mechanized, but involves material liability, then it requires, first of all, greater physical effort. Therefore, the requirements are higher for health, conditions and wages, and much less for the skills of work with computers, gender, education, etc. However, in real life, hired workers may not always meet the criteria of employers, which adversely affects the level of their competitiveness, because it depends on the influence of many factors.

In order to avoid disparity between the preferences of the above-mentioned respondent groups, it is necessary, in our opinion, to formulate leading components of the financial support for the competitiveness of the mining industry and determine the ways to increase the financing of the competitiveness of miners (Table 2). That means, the most important components and directions for financing to improve the competitiveness of miners are based on the implementation of measures for the preservation of human resources and their development in the short and long term. Thus, this approach envisages, above all, the following measures: financing of competitions concerning employment of miners according to clear criteria; financing of professional training and professional development of miners; financing of complex programs for employment, career growth and personnel rotation of specialists of all levels; financing of complex programs for the formation of the personnel reserve of miners according to their professional qualification and professional direction, etc.

Table 2. Leading components and directions for increasing the financial support of the competitiveness of mining workers in certain regions of Ukraine at macro and micro levels

\begin{tabular}{|c|c|c|c|}
\hline No. & Component, direction & \begin{tabular}{|c|} 
Macro \\
level
\end{tabular} & $\begin{array}{l}\text { Micro } \\
\text { level }\end{array}$ \\
\hline \multicolumn{4}{|c|}{ Funding of competitions for miners' employment according to clear criteria } \\
\hline & $\begin{array}{l}\text { Financing of leading scientific and practical specialists for the development } \\
\text { and implementation of specific and relevant criteria for the selection and } \\
\text { employment of miners. }\end{array}$ & - & + \\
\hline \multicolumn{4}{|c|}{ Financing of professional training and professional development of miners } \\
\hline & $\begin{array}{l}\text { Financing of higher and vocational education by prospective specialists of } \\
\text { the mining industry according to the needs of the labor market }\end{array}$ & + & + \\
\hline & $\begin{array}{l}\text { Financing of competitive projects to attract the most capable and active } \\
\text { youth to work in the mining industry. }\end{array}$ & + & + \\
\hline \multicolumn{4}{|c|}{$\begin{array}{c}\text { Financing of complex programs for employment, career growth and personnel rotation of } \\
\text { specialists of all levels }\end{array}$} \\
\hline & $\begin{array}{l}\text { Material incentives for miners working efficiently and effectively, taking } \\
\text { into account their organizational and professional abilities, including } \\
\text { prospect of their career growth. }\end{array}$ & - & + \\
\hline \multicolumn{4}{|c|}{$\begin{array}{c}\text { Financing of complex programs for the formation of a personnel reserve of miners according } \\
\text { to their professional qualification and professional direction }\end{array}$} \\
\hline & $\begin{array}{l}\text { Material incentives for the most promising future and current young } \\
\text { specialists in every work direction within the mining industry, promotion } \\
\text { of their professional development, improvement of their professional and } \\
\text { organizational skills and abilities and the possible assignment of each of } \\
\text { them to the position at any time }\end{array}$ & - & + \\
\hline
\end{tabular}


In our opinion, the aforementioned approach will be conducive to the differentiation at the macro and micro levels of influence levers on employment, income, employment, conditions and attitudes towards labor and competitiveness under the market conditions of future and current professionals in the mining industry.

Additionally, the effectiveness of the implementation of all the above measures depends on the approbation and the theoretical assessment of the developed concepts and models for increasing financial support measures for the competitiveness of the mining industry. This approach involves the implementation of certain interrelated stages (Fig. 2).

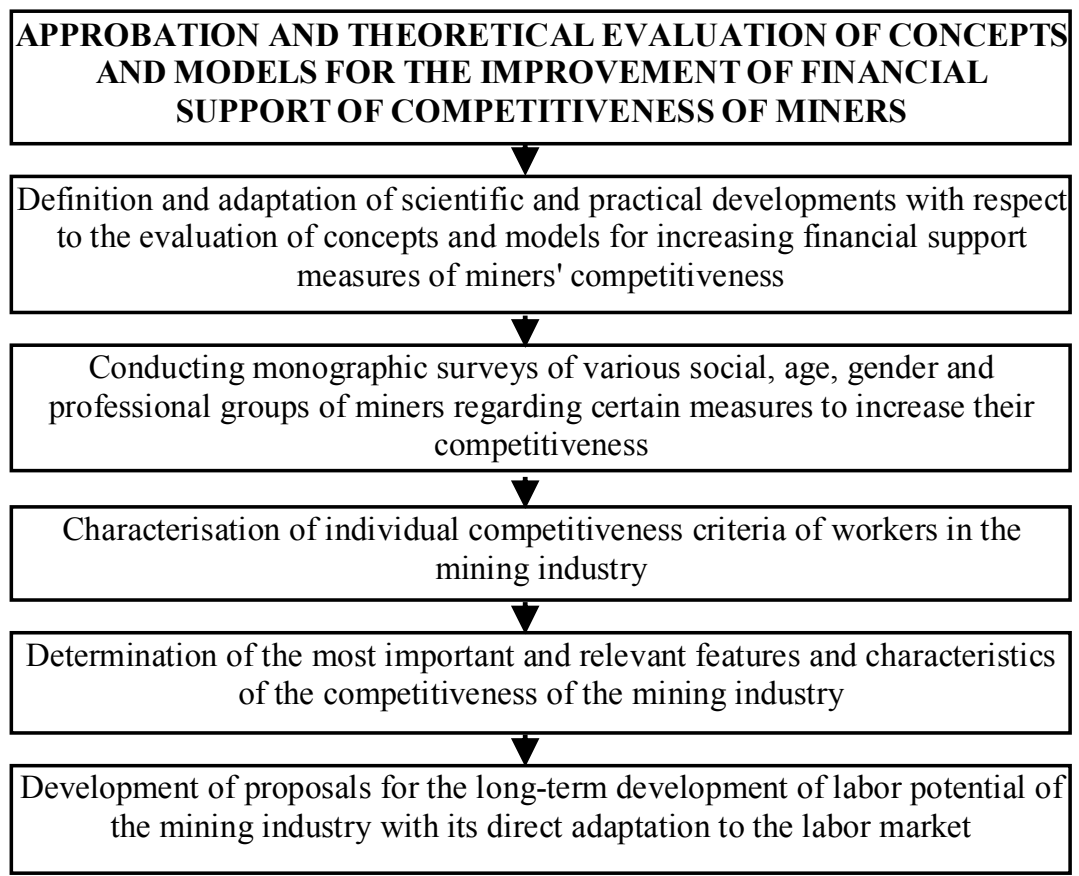

Fig. 2. The main stages of testing and theoretical assessment of concepts and models for increasing of financial support measures for the competitiveness of mining workers

Thus, the aforementioned approach involves a profound elaboration of theoretical concepts regarding the financing of human resources development in the mining industry and their effective practical implementation. At the same time, their application should help identify the most important components for improving the competitiveness of miners who need to improve, or to identify and finance the development of new ones.

In our opinion, the formation of a long-term strategy for financing the development of human resources capacity of the mining industry is an equally important stage in providing financial support towards miners' competitiveness. Thus, it should ensure the 
implementation of the following measures at the expense of public and private institutions at the macro and micro levels:

- financing the development and implementation of a comprehensive state program of employment of depressed regions and unprofitable sectors of the economy (identification of priority areas for training, and retraining of future and current workers in the mining industry);

- financing of the employment system by the state or private mining companies (with partially jobs guaranteed by the state) (allocation of state funds for employment of the population in the relevant economic entities);

- financing and formation of a state order for the training of future mining specialists, taking into account the state and prospects of the labor market in this area (reduction of ineffective state expenditures for the training of specialists for which there is no demand in the labor market and directing these funds towards support of employment and increase of incomes of mining employees);

- financing the improvement of qualification of miners in modern domestic and foreign technologically equipped enterprises, institutions and organizations (competitive selection of the best experts in the mining industry and payment of their internships in the respective economic entities);

- financing of the system of re-training of workers in the mining industry in relation to this field (related to this field may be any specialisation related to work in heavy industry and the processing industry);

- financing a program of employment of disabled people with occupational diseases obtained as a result of work in this area (preferential taxation of economic entities employing this category of population);

- privileged income taxation for employees of unprofitable mining companies (granting of tax privileges on personal income, a single social contribution, value added tax, corporate income tax, etc.), etc.

We believe that all the above measures will not only increase the competitiveness of the miners, but will also contribute to their effective employment in this area and the improvement of welfare in general. They can also be used as proposals for the effective implementation of financial support measures for the competitiveness of mining workers.

\section{Conclusion}

Thus, as a result of the analysis, we have established that the competitiveness of an employee of the mining industry implies his ability to fully exercise his right to work in an economic entity of the industry and receive an appropriate remuneration for it at any time.

Taking into account the aforementioned interpretation, we have identified the main stages of the financial provision of the competitiveness of the mining industry. They foresee: financial support of the scientific and practical process of determining the criteria for competitiveness of miners and conducting its sociological assessment; 
formation of the leading components of financial support for the competitiveness of workers in the mining industry; definition of directions for increasing financing of miners' competitiveness; approbation and theoretical assessment of the developed concepts and models of increasing the financial support measures of the mining industry's competitiveness; formation of a long-term strategy for financing the development of the human resources potential of the mining industry.

However, as a result of the monographic survey, we have established that there is a significant disparity between individual groups of respondents regarding the implementation of the above-mentioned stages. Thus, the activities of the heads of the mining enterprises and their deputies are aimed at minimizing the costs of human resources, while hired workers prefer to secure their own welfare at the expense of employers.

In order to avoid the above disparity, we have identified measures to increase the competitiveness of miners. They provide financial support for the implementation of professionally oriented personnel policies by employers for hired workers, periodically assessing the quality of work of each miner and providing them with appropriate material and socio-psychological incentives.

The above-mentioned approach will promote a higher level of competitiveness, employment and income of miners, as well as complex development of human resources potential of enterprises of the mining industry as a whole.

Further scientific research will examine the results of the application of the described stochastic positional model and the complex methodological approach to financial support for the competitiveness of mining workers at enterprises and substantiated the use of recommendations for the formation of a long-term strategy, including the application of preferential taxation of profits for workers of non-profit mining companies.

\section{References}

1. Statistical Yearbook of Ukraine for 2015. Government service of statistics of Ukraine, Kiev (2016)

2. Cardoso, A.: Behind the life cycle of coal: Socio-environmental liabilities of coal mining in Cesar, Colombia. Ecological Economics. 120, 71-82 (2015)

3. Chan, T.H.: Basic concepts economy forges production. Products of mineral-resource complex. Natural and productive potential. Molodoj uchenuj. 11.4, 229-232 (2015)

4. Fedotova, N.V., Fedotov, P.K., Zelynskaya, E.V.: Economics and Management mining production. Academia Estestvoznanyya, Moscow (2017)

5. Gayko, G.I., Beletsky, V.S.: History of Mining. Kievo-Mogylyanska academia, LADO, DonDTU, Kiev-Alchevsk (2013)

6. Ivanov, V.V., Komarov, V.M., Pavlov, P.N.: Questions of modernization: the role of social capital. Delo RANXyGS, Moscow (2014)

7. Kozlov, S.S.: Lecture on discipline - Occupational safety in the mining industry to prepare students of the Institute for Energy and Energy Efficiency qualification level "specialist" and "master". NTUU KPI, Kiev (2013) 
8. Mahdevari, S., Shahriar, K., Esfahanipour, A.: Human health and safety risks management in underground coal mines using fuzzy TOPSIS. Science of the Total Environment. 488, 85-99 (2014)

9. Maiti, J., Chatterjee, S., Bangdiwala, S.: Determinants of work injuries in mines - an application of structural equation modeling. Injury control and safety promotion. 11(1), 2937 (2004)

10. Mossakovskyy, Y.V.: Economy mining industry: a textbook is for higher educational. Gornaya knyga, Moscow (2014)

11. Nagornuy, V.P., Globa, V.M.: Mining. The road length in millennium. Akademperiodyka, Kiev (2014)

12. Polishchuk, L.I.: Or severally report. Social capital cities in development. Strelka Press, Moscow (2014)

13. Prno, J.: An analysis of factors leading to the establishment of a social licence to operate in the mining industry. Resources Policy. 38(4), 577-590 (2013)

14. Ryfkyn, J.: Financial capital against social capital Third Revolution: How horizontal interaction change Energy, economy and the world in general. Alpina non-fiction, Moscow (2014)

15. Dobrenkov, V.I. (ed.): American sociological thought. MSU, Moscow (1994)

16. Perevozova, I., Babenko, V., Kondur, O., Krykhovetska, Z., Daliak, N.: Financial support for the competitiveness of employees in the mining industry. SHS Web of Conferences. $\mathbf{6 5}$, 01001 (2019). doi:10.1051/shsconf/20196501001 